\title{
Common Cultural Turkish words in Albanian and Greek languages
}

\author{
Dr. Adem Balaban \\ Dr. Bünyamin Çağlayan \\ Department of Turkish Language and Literature \\ Hëna e Plotë-Bedër University, Tirana, Albanıa \\ Email: abalaban@beder.edu.al \\ Email: bcaglayan@beder.edu.al
}

Doi:10.5901/jesr.2014.v4n2p262

\begin{abstract}
The Balkans has a very important place in human civilization. In history, the Balkans has been the cradle of many cultures and hosted many nations. Greeks and Albanians living in these lands are oldest nations. Then, by the arrival of the Turks, these three nations became neighbors in the Balkans. Turkish, Greek and Albanian nations where influenced by each other. This interaction is to be seen mostly in cultural area. This interaction was more effective in the field of language, especially during the Ottoman period. Many words were transferred from Turkish to Greek and Albanian during this period. Some Greek words were also transferred to Turkish and Albanian. Many words are commonly used, particularly in cultural areas and they are still used. Common words used in these areas Kitchen, tailoring, shipping, customs, weddings and other cultural aspects are indicators of a common culture. In our study, Turkish, Albanian and Greek common Turkish words which reflect the common cultural elements will be handled. We will also discuss the words which reflect the common cultural elements.
\end{abstract}

Keywords: Turkish, Albanian, Greek, common words, culture

\section{Introduction}

Language is one of the most important features that separate man from other assets. Human beings as thinking give names to objects and some concepts and created the language. The language is occurred by the agreement. It has been the most powerful means of communication between people. Since very ancient times, researchers made many different definitions about the language. One of these definitions is sufficient. According to Ergin, "The language is a natural tool of understanding among the people. It has its own rules and develops in these rules. Its base was established unknown periods of history. It is a secret agreement which occurred from sounds. It is also a social institution. (Ergin, 2008:3)

Culture encompasses everything from the food, drink, dress, style of living up to moral values. It was the most important elements that make up society since the first human being. In general, culture which is considered as the main identity of a nation's has been incorporated with the language. According to the definition of UNESCO; "that in its widest sense, culture may now be said to be the whole complex of distinctive spiritual, material, intellectual and emotional features that characterize a society or social group. It includes not only the arts and letters, but also modes of life, the fundamental rights of the human being, value systems, traditions and beliefs". (UNESCO, 1982:2)

Many disciplines interest in culture from language to literature, anthropology, history etc. Because every branches of science that are interesting in human being evaluated their own culture which developed in it. Gökalp who is referring to this fact says about the culture:

"Culture is a compatible collection of religion, morality, law, mind, aesthetics, language, economics and philosophy about only one nation life. On the other hand, civilization is the sum of a common social life of many nations which are the same level of development. (Gökalp, 1997:25)

In time, people form their own cultural world according to the conditions of their culture, the rights and freedoms, geographical, physical and spiritual conditions. What are they more engaged in their region these cultural items keep in the place in their culture. There are a lot of cultural differences between nomadic society and sedentary society. Human beings have needed making a name each new object or notion. This nomenclature is sometimes taken from one language to another, sometimes the folks made it into their own language.

In generally, all material and moral elements that are into the culture of a nation are reflected in their languages. In this respect, there are some words that show each elements of the culture and provide information about this culture. 
This also means that culture has influence upon the language and language is the main elements which reflect cultural elements.

Since the time immemorial, the relationship between language and culture has attracted the attention of sociologists and linguists as well. Language and culture, studies on the relationship between language and society has given rise to a new discipline called ethno linguistic. Sapir who is considered the founder of the "Ethnic linguistics" rejected the idea of transferability of the cultural characteristics one culture to another independently from the people. Sapir focused on the correlation between the individual's perception and cognitive faculties in order to explain that people who have the different behaviors, language and cultural background. (Moore, 2004, p.89-90 in Oğuz, 2011:134).

According to Kaplan who said that in a very tight relationship between language and culture: "Every nation creates language and culture for centuries. In the meantime, it flows like a river that passes through land takes some of the elements from the earth. Every civilized nation's spoken and written language has many words and phrases that were transferred from encountered civilizations. In this regard, the language of every nation is almost a summary of the history of the nation lived through the ages." (Kaplan, 2011:152).

According to Aksan who said "Language contains all the elements of culture": "If one foreigner who doesn't know Turkish and has been in neither Anatolia nor other Turkic countries learns Turkish in anywhere all over the world can acquire a lot of information on the Turkish culture and is able to recognize that culture by just studying Turkish vocabulary. (Aksan, 2011:21)

"Through all its verbal and non-verbal aspects, language embodies cultural reality." "Language is a system of signs that is seen as having itself a cultural value. Speakers identify themselves and others through their use of language; the wiev their language as a symbol of their social identity. The prohibition of its use is often perceived by its speakers as a rejection of their social group and their culture. Thus we can say that language symbolizes cultural reality." (Kramsch, 2003:3).

In this study, we will focus on Turkish linguistic elements in Greek and Albanian languages. These works have been used in the determination of Turkish words in Greek:

- Common Turkish and Greek Idioms and Proverbs (Türkçe Ve Yunancadki Ortak Deyim Ve Atasözleri) written by Herkül Milas,

- The dictionary of Turkish Words That Transferred Other Languages(Türkçe Verintiler Sözlüğü) written by Günay Karaağaç,

- Turkish Cultural Words in Balkan Languages (Balkan Dillerindeki Türkçe Kültür Kelimeleri) written by Hatice Aksel

- The Evaluation Of The Joint Vocabulary In Turkish And Greek In Point Of The Cross-Cultural Interaction (Kültürlerarası Etkileşim Bağlamında Türkçe ve Yunancadaki Ortak Sözvarlığının Değerlendirilmesi) written by Mustafa Yağbasan

In the Albanian, in order to identify the determination of Turkish words into Greek and Albanian languages we benefited from these works:

- Dictionary of Oriantalistic Words in Albanian (Fjalor i Oriantalizmave Në Gjuhën Shqipe) written by Tahir N. Dizdari

- Turkish Words In Albanian Language And Comparing Them With Other Balkan Languages (Mbi Huazimet Turke Në Gjuhën Shqipe Krahasuar Me Gjuhët E Tjera Të Ballkanit) written by Lindita Latifi xhanari

- The Evaluation Of The Joint Vocabulary In Turkish And Greek In Point Of The Cross-Cultural Interaction (Kültürlerarası Etkileşim Bağlamında Türkçe ve Yunancadaki Ortak Sözvarlığının Değerlendirilmesi) written by Mustafa Yağbasan

- The Sound Changes in Turkish Words in Albanian Language (Türkçeden Arnavutçaya Geçen Kelimelerdeki Ses Değişmeleri) written by Adem Balaban

In this study, we firstly determined which cultural titles shall be and which words shall be collected under these titles. In the distinction made by the fields of cultural elements, the linguistic elements are listed in alphabetical order under these titles. When we are choosing the words, we preferred them which are used in daily language.

One language's influence on other language is not to be only their own linguistic elements. Sometimes linguistic element is transferred to other language as a meaning; sometimes new indicators are produced in that language according to affecting language. In such cases, linguistic elements can be changed but cultural indicators are not changed. In this study, we tried to show examples of Turkish linguistic indicators in Albanian and Greek languages.

When we show examples in these three languages, tried to give in Greek, Albanian and Turkish forms due to phonetics and morphologic changes in these words. Furthermore, English forms of these words are also given to the 
source of other researchers.

\section{The Relationships between Turkish, Greek and Albanian}

Turks migrated from the steppes of Central Asia into Europe during the emigration of the nations. At the end of this migration, Turks who settled in Europe, including the Balkans interacted with other nations living there in many areas. The interaction which started at this period rose to the highest level during the Ottoman period. This interaction has been most effectively on language and culture fields. Especially during the Ottoman period, Turkish and Turkish culture has influenced many Balkan languages and cultures. This interaction occurred mostly in Serbian, Bosnian, Albanian and Greek. In particular, Serbian, Greek and Albanian transferred many words from Turkish.

Karaağaç explains that there are approximately 3000 Turkish words in Greek at his study of "Dictionary of Turkish Words in Other Languages (Türkçe Verintiler Sözlüğü)". (Karaağaç, 2008:LXIV). According to the researchers working on the Turkish words in Greek, these numbers ranged from 1500-3000. According to Karaağaç, the presence of Turkish words in Greek is 3000 in the study of Kukkidis in 1960. This number is 1968 in the study of Georgidas in 1974. There are Turkish words in "Etymological Dictionary of Giagkoullis" in 1994. (Karaağaç, 2008:LXIV)

Exchanging the word was not unilateral. At the same time, Turkish also transferred Greek words. According to Karaağaç, the number of these words are 900 in Konstantinos's study in 1960 and this number is 597 in Tzitzilis's book published in 1987. (Karaağaç, 2008:LXIII)

There are also many Turkish words in Albanian which affected by Turkish. According to Dizdari, the number of these words is 4406. (Dizdari, 2005:4)

As it is seen, to be used very common word shows that these three nations affected each other in terms of culture. Language which is a carrier of culture transferred cultural values from one society to another due to these cultural words. This cultural transfer and approaches are observed not only the linguistic level but also many areas such as lifestyle, social life etc. "In Turkish and Greek communities, the conclusions can be obtained from the common linguistic indicators as well as behavior is reflected in the social and cultural factors. (Yağbasan, 2010:369)

Any foreign word in a language carries marks its cultural layer. According to Aksan, "The word related catering, cuisine and nutrition shows the layout of feeding in a community. The foreign names within the one language's vocabulary bring out the effects of other culture." (Aksan 1998:66)

In the history, the Turks, Albanians and Greeks lived together as neighbors a long time. As a result of these relationships languages and cultures influenced each other. According to Aksan, sharing the same geography plays linguistically an important role in this interaction. Aksan expresses it like this:

"As a conclusion of the sharing of the same geography by different communities, the continuity of the words exchange is observed in the historical process. Moreover, it may be witnessing that the situation that are explained above changes the face of the languages." (Aksan, 1998:139).

According to Yağbasan who is referring to this issue, "The neighborhood is an undeniable fact that the effect of the existence of the relationship. Geographical and theological neighborhood and proximity makes exchange between the languages natural." (Yağbasan, 2010:371)

\section{Cultural Items}

Every nation lived in a system of customs, their faith, morals, law, education etc. in the historical process. This lifestyle and worldview provided that every nation has its own culture. Culture which contains a number of items in their own culture influenced them as well as they have developed through life style and philosophy of life. Major elements of culture include:

a. Language,

b. Religion,

c. Education,

d. Economics,

e. Technology,

f. Social Institutions

g. Traditions And Customs,

a. Moral Values

b. Art, 

c. Literature,
d. Folklore,
e. Music
f. Symbols
g. Taboos And Ceremonies

Many researchers have made various divisions on the reflection of the cultural elements to the linguistic indicators. We try to give our own classification because capacity of this study was not sufficient to count them.
1. Plant names
2. Animal Names
3. Food culture
4. Goods, material or object words
5. Maritime-related words
6. Argo words
7. Business and Money, weight, number and size
8. Everyday cultural (abstract) words
9. Urban Planning, building, building materials and related words with hand tools
10. Nomenculaton words
11. Games - fun words
12. Military (war and peace) concepts and words
13. Business, Occupational and Vocational names; Vocational Equipment and Supplies
14. Geographical terms
15. Clothing and Finery, Fabrics, Leather, Rope, Embroidery and Accessories
16. Terms of Medicine and Health, Human and Animal limbs
17. Paint, Color, Fragrance and Cosmetic

\section{Turkish Cultural Words in Greek and Albanian}

Turkish words in Greek that are still being used in the present, distribution of these words are possible to tabulate the following way. Yağbasan made a classification on the daily used words. (Yağbasan, 210:71)

Table 1: Classification on the daily used words.

\begin{tabular}{|c|l|c|}
\hline Nr. & \multicolumn{1}{|c|}{ Cultural Topic } & Number \\
\hline 1 & Plants (vegetables, fruit), and the presence of food & 99 \\
\hline 2 & Goods, material or object words & 72 \\
\hline 3 & Street (slang) language words & 37 \\
\hline 4 & Seafood and seafood related words & 32 \\
\hline 5 & Cultural frequently used words in some mixed & 31 \\
\hline 6 & Everyday cultural (abstract) words & 24 \\
\hline 7 & Everyday (concrete) words & 12 \\
\hline 8 & Building, construction materials and hand tools related words & 28 \\
\hline 9 & Nomenculaton words & 18 \\
\hline 10 & Games - fun words & 18 \\
\hline 11 & Military (war and peace) concepts and words & 14 \\
\hline 12 & Theological words and phrases & 12 \\
\hline 13 & Agricultural words & 10 \\
\hline 14 & Geographical terms & 9 \\
\hline 15 & Occupational words & 6 \\
\hline 16 & Animal names & 2 \\
\hline 17 & Element words & 430 \\
\hline
\end{tabular}

According to the study which is studied by Aksel on the all Balkan languages, Albanian, Turkish and Greek words used in the distribution of co-culture are as follows: (Aksel, 2005:12) (Aksel, 2005:12) 
Table 2: The culturel topics which Albanian, Turkish and Greek words are used

\begin{tabular}{|c|l|c|c|c|}
\hline Nr. & \multicolumn{1}{|c|}{ Cultural Topic } & $\begin{array}{c}\text { Number of Words } \\
\text { Used in Albanian }\end{array}$ & $\begin{array}{c}\text { Number of Words } \\
\text { Used in Greek }\end{array}$ & $\begin{array}{c}\text { Number of Commonly } \\
\text { Used Words }\end{array}$ \\
\hline 1 & $\begin{array}{l}\text { Urban planning, construction, building elements } \\
\text { and materials }\end{array}$ & 96 & 63 & 116 \\
\hline 2 & $\begin{array}{l}\text { Business, occupational and vocational names; } \\
\text { vocational equipment and supplies }\end{array}$ & 148 & 122 & 77 \\
\hline 3 & Household and kitchenware & 140 & 84 & 75 \\
\hline 4 & $\begin{array}{l}\text { lothing and finery, fabrics, leather, rope, } \\
\text { embroidery and accessories }\end{array}$ & 110 & 89 & 23 \\
\hline 5 & Food and beverages, spices & 44 & 37 & 47 \\
\hline 6 & Plant names & 65 & 64 & 28 \\
\hline 7 & Animal names & 31 & 23 & 6 \\
\hline 8 & Business and money, weight, number and size & 62 & 35 & 12 \\
\hline 9 & Horses and horse teams & 21 & 8 & 14 \\
\hline 10 & $\begin{array}{l}\text { lerms of medicine and health, human and animal } \\
\text { limbs }\end{array}$ & 37 & 16 & 5 \\
\hline 11 & Metals, stones and chemical substances & 33 & 19 & 8 \\
\hline 12 & Paint, color, fragrance and cosmetic & 14 & 11 & 473 \\
\hline 13 & Verbs & 42 & 523 & \\
\hline & 843 & & \\
\hline
\end{tabular}

According to classification of the above, we offer the following to set an example for the list from a portion of the detected words. We tried to choose the words very different cultural areas to give an idea of the general.

\subsection{Plant names}

$\begin{array}{ll}\text { English } & \text { Turkish } \\ \text { Okra } & \text { Bamya } \\ \text { Tea } & \text { Çay } \\ \text { Hurma } & \text { Hurma } \\ \text { Clove } & \text { Karanfil } \\ \text { Beans } & \text { Fasulye } \\ \text { Medlar } & \text { Muşmula } \\ \text { Lettuce } & \text { Marul }\end{array}$

\subsection{Animal Names}

\section{English}

Animal

Tiger

Monkey

Goat

Stork

Coyote

Nightingale

\subsection{Food Culture}

English
Baklava
Patty
Halvah
Kadayif
Cream
Meatball
Rice

English

Halvah

Kadayı

Meatball

Rice

Turkish
Hayvan
Kaplan
Maymun
Keçi
Leylek
Çakal
Bülbül

Turkish

Baklava

Börek

Helva

Kadayıf

Kaymak

Köfte

Pilav

Albanian
Bamje
Çaj
Hurma
Karafil
Fasule
Mushmula
Marule

Greek

Bamia

Tsai

Hurmas

Karafilli

Fasoulia

Mousmoula

Maruli

$\begin{array}{ll}\text { Albanian } & \text { Greek } \\ \text { Hajvan } & \text { Haivani } \\ \text { Kapllan } & \text { Kaplani } \\ \text { Majmun } & \text { Maymu } \\ \text { Kec, Keci } & \text { Katsika } \\ \text { Lejlek } & \text { Leleki } \\ \text { Çakall } & \text { Cakal } \\ \text { Bilbil } & \text { Bülbül }\end{array}$

Haivani

Kaplani

Maymu

Cakal

Albanian
Bakllava
Byrek
Hallvë
Kadaif
Kajmak
Qofte
Pilaf

Albanian

Byrek

Hallvë

Kadaif

Qofte 
4.4 Goods, Material Or Object Words

$\begin{array}{llll}\text { English } & \text { Turkish } & \text { Albanian } & \text { Greek } \\ \text { Glass } & \text { Cam } & \text { Xham } & \text { Tzami } \\ \text { Arbor } & \text { Çardak } & \text { Çardak } & \text { Tsardaki } \\ \text { Socks } & \text { Çorap } & \text { Çorape } & \text { Tsurapis } \\ \text { Cup } & \text { Fincan } & \text { Filxhan } & \text { Flitzani } \\ \text { Box } & \text { Kutu } & \text { Kuti } & \text { Kouti } \\ \text { Curtain } & \text { Perde } & \text { Perde } & \text { Berdes } \\ \text { Cap } & \text { Kapak } & \text { Kapak } & \text { Kapaki }\end{array}$

\subsection{Maritime-Related Words}

$\begin{array}{llll}\text { English } & \text { Turkish } & \text { Albanian } & \text { Greek } \\ \text { Octopus } & \text { Ahtapot } & \text { Oktapod } & \text { Htapodi } \\ \text { Gilt-Head/Bream } & \text { ÇipuralKoc } & \text { Çipura } & \text { Tsipura } \\ \text { Mussel } & \text { Midye } & \text { Midhje } & \text { Midia } \\ \text { Squid } & \text { Kalamar } & \text { Kallamar } & \text { Kalamari } \\ \text { Boat } & \text { Sandal } & \text { Sandall } & \text { Sandali } \\ \text { Gray Mullet } & \text { Kefal } & \text { Kefall } & \text { Kefalos } \\ \text { Port } & \text { Liman } & \text { Liman } & \text { Limani }\end{array}$

4.6 Argo Words

$\begin{array}{llll}\text { English } & \text { Turkish } & \text { Albanian } & \text { Greek } \\ \text { Crook } & \text { Batakçı } & \text { Batakçi } & \text { Bataxis } \\ \text { Trouble } & \text { Bela } & \text { Bela } & \text { Belas } \\ \text { Fool } & \text { Budala } & \text { Budalla } & \text { Boudalas } \\ \text { Rip } & \text { Çapkın } & \text { Çapkën } & \text { Tsahpinis } \\ \text { Deception } & \text { Dallavere } & \text { Dalavere } & \text { Dalavere } \\ \text { Maniac } & \text { Manyak } & \text { Maniak } & \text { Manyakos } \\ \text { Infamous } & \text { Rezil } & \text { Rezili } & \text { Rezil }\end{array}$

4.7 Business And Money, Weight, Number And Size

$\begin{array}{llll}\text { English } & \text { Turkish } & \text { Albanian } & \text { Greek } \\ \text { Bazar } & \text { Pazar } & \text { Pazar } & \text { Pazari } \\ \text { Dinar } & \text { Dinar } & \text { Dinar } & \text { Dhinario } \\ \text { Tribute } & \text { Haraç } & \text { Haraç } & \text { Hartsi } \\ \text { Rent } & \text { Kira } & \text { Qira } & \text { Kira } \\ \text { Money } & \text { Para } & \text { Para } & \text { Paras }\end{array}$

4.8 Everyday Cultural (Abstract) Words

$\begin{array}{llll}\text { English } & \text { Turkish } & \text { Albanian } & \text { Greek } \\ \text { Lover } & \text { Aşık } & \text { Ashik } & \text { Asikis } \\ \text { Fertility } & \text { Bereket } & \text { Bereqet } & \text { Bereket } \\ \text { Crowd } & \text { Kalaballk } & \text { Kallaballëk } & \text { Kalabaliki } \\ \text { Worry } & \text { Dert } & \text { Dert } & \text { Derti } \\ \text { Oh } & \text { Aman } & \text { Aman } & \text { Aman } \\ \text { Affectation } & \text { Naz } & \text { Nazi } & \text { Naz } \\ \text { Love } & \text { Sevda } & \text { Sevda } & \text { Sevdas }\end{array}$

4.9 Urban Planning, Building, Building Materials And Related Words With Hand Tools

$\begin{array}{llll}\text { English } & \text { Turkish } & \text { Albanian } & \text { Greek } \\ \text { Arbor } & \text { Çardak } & \text { Çardak } & \text { Tsardhaki } \\ \text { Bath } & \text { Hamam } & \text { Hamam } & \text { Hamam }\end{array}$




$\begin{array}{llll}\text { Inn } & \text { Han } & \text { Han } & \text { Han } \\ \text { Toilet } & \text { Hela } & \text { Hale } & \text { Hales } \\ \text { Coffee Shop } & \text { Kahvehane } & \text { Kafehane } & \text { Kahvenio } \\ \text { Mansion } & \text { Konak } & \text { Konak } & \text { Konak } \\ \text { Sewer } & \text { Lağım } & \text { Llagëm } & \text { Lagami }\end{array}$

\subsection{Nomenculaton Words}

$\begin{array}{llll}\text { English } & \text { Turkish } & \text { Albanian } & \text { Greek } \\ \text { Father } & \text { Baba } & \text { Baba, Atë } & \text { Babas } \\ \text { Bey } & \text { Bey } & \text { Bej } & \text { Beis } \\ \text { Master } & \text { Efendi } & \text { Efendi } & \text { Afendis } \\ \text { Porter } & \text { Hamal } & \text { Hamall } & \text { Hamalis } \\ \text { Guest } & \text { Misafir } & \text { Mysafir } & \text { Musafiris } \\ \text { Single } & \text { Bekâr } & \text { Beqar } & \text { Bekaris } \\ \text { Lady } & \text { Hanım } & \text { Hanëm } & \text { Hanomisa }\end{array}$

\subsection{Games - Fun Words}

$\begin{array}{llll}\text { English } & \text { Turkish } & \text { Albanian } & \text { Greek } \\ - & \text { Karagöz } & \text { Karagjoz } & \text { Karagoz } \\ - & \text { Çiftetelli } & \text { Çifteteli } & \text { Tsiftetelli } \\ \text { Drum } & \text { Tambur } & \text { Daulle } & \text { Tambouras } \\ \text { Clarion } & \text { Zurna } & \text { Zurna } & \text { Zurnas } \\ \text { Reed } & \text { Saz } & \text { Saz } & \text { Sazi } \\ \text { Membrane } & \text { Zar } & \text { Zari } & \text { Zar } \\ \text { Fair } & \text { Panayır } & \text { Panair } & \text { Panigyri }\end{array}$

4.12 Military (War And Peace) Concepts And Words

$\begin{array}{llll}\text { English } & \text { Turkish } & \text { Albanian } & \text { Greek } \\ \text { Flag } & \text { Bayrak } & \text { Bajrak } & \text { Bairaki } \\ \text { Edict } & \text { Ferman } & \text { Ferman } & \text { Firmani } \\ \text { Cartridge } & \text { Fişek } & \text { Fishek } & \text { Fiseki } \\ \text { Rifle } & \text { Tüfek } & \text { Dyfek } & \text { Toufeki } \\ \text { Order } & \text { Tertip } & \text { Tertip } & \text { Tertipi } \\ \text { Powder } & \text { Barut } & \text { Barut } & \text { Baruti } \\ \text { Wick } & \text { Fitil } & \text { Fitil } & \text { Fitili }\end{array}$

4.13 Business, Occupational And Vocational Names; Vocational Equipment And Supplies

$\begin{array}{llll}\text { English } & \text { Turkish } & \text { Albanian } & \text { Greek } \\ \text { Barber } & \text { Berber } & \text { Berber } & \text { Berberis } \\ \text { Apprentice } & \text { Çırak } & \text { Çirak } & \text { Tsiraki } \\ \text { Shepherd } & \text { Çoban } & \text { Coban } & \text { Tsobanis } \\ \text { Tinsmith } & \text { Kalaycl } & \text { Kalajxhi,Teneqepunues Kalaitzis } \\ \text { Carpenter } & \text { Marangoz } & \text { Marangoz } & \text { Marangos } \\ \text { Artisan } & \text { Esnaf } & \text { Esnaf } & \text { Sinafi } \\ \text { Halvaci } & \text { Helvacl } & \text { Hallvaxhi } & \text { Halvatsi }\end{array}$

\subsection{Geographical Terms}

\section{English \\ Breeze \\ Map \\ Top \\ World \\ Weather \\ Gust}

Turkish
Meltem
Harita
Tepe
Dünya
Hava
Bora

Albanian
Meltem
Hartë
Tepe
Dünja
Hava
Bor

Greek

Meltemi

Hartis

Tepes

Dounya

Havas

Bora 
$\begin{array}{lll}\text { Square Meydan } & \text { Mejdan } & \text { Meidani }\end{array}$

4.15 Clothing And Finery, Fabrics, Leather, Rope, Embroidery And Accessories

$\begin{array}{llll}\text { English } & \text { Turkish } & \text { Albanian } & \text { Greek } \\ \text { Entari } & \text { Entari } & \text { Entari } & \text { Aderi } \\ \text { Socks } & \text { Çorap } & \text { Çorape } & \text { Tsorapi } \\ \text { Broadcloth } & \text { Çuha } & \text { Çuha } & \text { Tsuha } \\ \text { Bundle } & \text { Bohça } & \text { Bohçe } & \text { Bogos } \\ \text { Fistan } & \text { Fistan } & \text { Fistan } & \text { Fistani } \\ \text { Turban } & \text { Sarı } & \text { Sarrëk } & \text { Sariki } \\ \text { Vest } & \text { Yelek } & \text { Jelek } & \text { Geleko }\end{array}$

4.16 Terms Of Medicine And Health, Human And Animal Limbs

$\begin{array}{llll}\text { English } & \text { Turkish } & \text { Albanian } & \text { Greek } \\ \text { Crippled } & \text { Sakat } & \text { Sakat } & \text { Sakatis } \\ \text { Syrup } & \text { Şurup } & \text { Shurup } & \text { Surupi } \\ \text { Syringe } & \text { Şırınga } & \text { Shiringë } & \text { Siriga } \\ \text { Pill } & \text { Hap } & \text { Hapje } & \text { Hapi } \\ \text { Crazy } & \text { Deli } & \text { Deli } & \text { Deliş } \\ \text { Asthma } & \text { Astım } & \text { Astmë } & \text { Astma } \\ - & \text { Sedef } & \text { Sedef } & \text { Sedefinos }\end{array}$

\subsection{Paint, Color, Fragrance And Cosmetic}

$\begin{array}{llll}\text { English } & \text { Turkish } & \text { Albanian } & \text { Greek } \\ \text { Tin } & \text { Kalay } & \text { Kallaj } & \text { Kalai } \\ \text { Recina } & \text { Recina } & \text { Recina } & \text { Retsini } \\ \text { Varnish } & \text { Vernik } & \text { Vernik } & \text { Verniki } \\ \text { Paint } & \text { Boya } & \text { Bojë } & \text { Bogia }\end{array}$

\section{Conclusion}

The Turks, Albanians and Greeks who lived next to each other in the history. They are influenced from each other and influenced each other in terms of the language and culture. During the Ottoman period, this interaction has occurred mostly Turkish and Turkish language influence on the others. In this interaction, many of Turkish words were transferred to Greek and Albanian. Turkish quoted words in Greek and Albanian moved to the Turkish culture to Greek and Albanian culture. In our study, 473 Turkish words with a common cultural value have been identified. These Turkish words are classified under the headings of culture and are given their spellings in Greek, Albanian and English. As shown in the above, the majority of the elements of Turkish cultural words in Greek and Albanian show that these nations have common values in many cultural fields.

These days which people are othering some people under the pretext of the smallest issues and people are increasing feelings of hatred, people should meet at least one of the commons and work to make the world a happy and peaceful. To accomplish this is not to be keeping alive some negative and false things in history but can be achieved with an emphasis on good things in history

In this subject all scientists should be in the role. Some inaccuracies in history are not related to nations but they should be given to person. These errors were usually made by those who have been living at the time administrators and intellectuals. In fact, they were also person and could make some mistakes. These mistakes should not cost a whole nation, they should not transformed into hatred between nations.

Instead of hatred, fights and war, some common features that arising from the partnerships with number of lives. These are the cultural, linguistic common features. The issue will serve two nations to approach and to love each other.

Pulling attention to the existence of a number of linguistic and cultural partnerships between the two nations will serve to keep alive the friendship between the two nations. This situation also will contribute to world peace. 


\section{References}

Aksan Doğan. (1998) Her Yönüyle Dil - Ana Çizgileriyle Dilbilim, Türk Dil Kurumu Yayınları, Ankara.

Aksan, Doğan. (1996) Türkçe’nin Sözvarlığı - Türk Dilinin Sözcükbilimiyle İlgili Gözlemler, Saptamalar, Engin Yayınevi, Ankara.

Aksan, Doğan. (2011) Türkçeye Yansıyan Türk Kültürü, 2nd ed.., Bilgi Yayınevi, Ankara.

Balaban, Adem. (2012) Türkçeden Arnavutçaya Geçen Kelimelerdeki Ses Değişmeleri, 7. Türk Dili Kurultayı, Ankara.

Dizdari, Tahir N. (2005) Fjalor i Oriantalizmave Në Gjuhën Shqipe, AlITC, Tiranë,

Ergin, Muharrem. (2008) Türk Dil Bilgisi, Bayrak Basım Yay., İstanbul,

Evangelia, A. (1998) Ödünçleme Süreci ve Dilbilimsel Görünümleri: Türkçe ve Yunanca'da Ödünçlemeler. Ankara Üniversitesi, Sosyal Bilimler Enstitüsü, Master Thesis, Ankara.

Gökalp, Ziya. (1997). Türkçülüğün Esasları, $5^{\text {th }}$ ed.. İnkılap Kitabevi, İstanbul.

Gürel, S. Ş. (1993) Türk-Yunan Ilişkileri, Ümit Yayıncılık, 1'st ed., Ankara.

Kaplan, Mehmet. (2011) Kültür ve Dil, Dergah Yay., 27th ed. İstanbul.

Karaağaç, Günay. (2008) Türkçe Verintiler Sözlüğü, TDK Yayınları, Ankara.

Kramsch, Claire. (2003) Language and Culture, Oxford Universty Press, $4^{\text {th }}$ ed., Oxford.

Latifi, Lindita. (2006) Mbi Huazimet Turke në Gjuhën Shqipe Krahasuar me Gjuhët e Tjera të Ballkanit, DUDAJ, Tiranë.

UNESCO, Mexico City Declaration on Cultural Policies World Conference on Cultural Policies, Mexico City, 26 July - 6 August 1982. http://portal.unesco.org/culture/en/files/12762/11295421661mexico_en.pdf/mexico_en.pdf), 15/09/2013.

Millas, Herkül. (2012) Türkçe - Yunanca Ortak Kelimeler, Deyimler ve Atasözleri, İstos Yayınları, İstanbul.

Oğuz, Esin Sultan. (2011) Toplum Bilimlerinde Kültür Kavramı, Edebiyat Fakültesi Dergisi, vol.28, issue. 2, pp.123-139.

Taneri A. (t.y.) Türk-Yunan Kültür Savaşı, Ocak Yayınları, Ankara.

Yağbasan, Mustafa (2010). Kültürlerarası Etkileşim Bağlamında Türkçe ve Yunancadaki Ortak Sözvarlığının Değerlendirilmesi, Fırat Üniversitesi Sosyal Bilimler Dergisi, vol: 20, issue: 1, pp: 367-388. 